Zinaida N. BAKALOVA,

Grand Ph.D. in Philological Sciences, Professor, Russian language, culture of speech and methods of their tuition Chair, Samara State Academy of Social Sciences and Humanities,

65/67 M. Gorjkogo st., Samara, 443099, Russia; tel.: +7 9276975035

e-mail: abakalov1941@yandex.ru; ORCID ID: 0000-0002-6766-8000

Elena A. KRASNOVA,

PhD (Philology), Associate Professor, Linguistics chair, Samara State Transport University,

2V, Svobody st., Samara, 443066, Russia; tel.: +7927 6547103; e-mail: eakrasnova@mail.ru;

ORCID ID: $0000-0002-3100-9310$

\title{
LINGUISTIC REPRESENTATION OF LOVE IN TALES BY I. A. BUNIN
}

Summary. The purpose of this article is to characterize specifics of linguistic presentation of love relations between man and woman in I. A. Bunin's idiostyle. Object of given analysis are three tales by I. A. Bunin: "Mitya's Love", "Sun Blow" and the first tale of the tale's cycle "Dark alleys" with the same title. Subject of our analysis are various linguistic markers and ways in usage by author revealing the state of love. Application of contextual analysis enabled a description of distinctive features in the style by the talented writer. The result of the research is not an inventory of author's main linguistic ways and methods only, but also formula of theoretical, methodological and methodical regulations as base for representation of linguistic methods in their possible tangle. The main conclusions are as follows. Forms of author's means and estimations are infinite. The whole arsenal of linguistic methods can be to author's disposal. Any linguistic construction can tell much to interested reader about author's creative style and manner. The task of the researcher is to reveal over serious recognition specific features and rates of efficiency of his artificial text. Practical application of investigation's results is possible in process of higher schools training course at philological analysis of artificial texts.

Key words: linguistic representation, linguistic markers and methods, method of contextual analysis, discourse method, theme of love, I. A. Bunin idiostyle.

Статтю отримано 4.10.2017 p.

http://dx.doi.org/10.18524/2307-4558.2017.28.112675

УдК 821.161.2:111.852

ВАКУ ЛИК Ірина Іванівна,

кандидат філологічних наук, доцент кафедри української та класичних мов Національного університету біоресурсів і природокористування України; вул. Героїв Оборони, 15, м. Київ, 03041, Україна, тел.: +38 0506245508 ; e-mail: vakulyk@ukr.net; ORCID ID: 0000-0002-4812-7719

\section{БАЛАЛАСВА Олена Юріївна,}

кандидат педагогічних наук, старший викладач кафедри української та класичних мов

Національного університету біоресурсів і природокористування України;

вул. Героїв Оборони, 15, м. Київ, 03041, Україна, тел.: +38 0687177254 ;

e-mail: olena.balalaeva@gmail.com; ORCID ID: 0000-0002-2675-5554

\section{AD FONTES: ФОРМУВАННЯ ЕСТЕТИЧНОЇ ПЛАТФОРМИ У ТВОРЧОСТІ М. ЗЕРОВА І М. РИЛЬСЬКОГО}

Анотація. Мета статті - проаналізувати специфіку рецепції античних мотивів і образів у літературній спадщині українських неокласиків початку XX ст., зокрема М. Зерова і М. Рильського. Творчість представників неокласики розглядається в культурологічному та літературознавчому аспектах. Предметом розгляду є трансформація античних символів як механізмів (пам'яті культури» і семіотичних конденсаторів в синхронії тексту. Результат дослідження. У праці доведено, що незважаючи на спільне для неокласиків тяжіння до калокагатії як естетичного ідеалу античної культури, яка передбачала гармонію почуттів раціональної сфери, тілесного і духовного начал, високої культури мислення й дисципліни поетичного мовлення, естетична платформа не зводиться до принципів "чистого класицизму», трактування класичних форм і принципів як універсальних і незмінних норм. Висновки. Представники доби “розстріляного відродження) залишили неоціненну спадщину. Творчість неокласиків є результатом взаємодії традицій і новацій, національних тенденцій із запозиченим і трансформованим досвідом рецепції античного тексту у світовій літературі. М. Зеров і М. Рильський розвинули українську поетичну традицію, збагатили українську поезію надбаннями античної літератури.

Ключові слова: українські неокласики, античність, рецепція, семіозис, естетичний ідеал, ad fontes. 
Постановка проблеми. Творчість українських неокласиків як представників доби “розстріляного відродження), які залишили неоціненну спадщину і зробили величезний внесок у збагачення не лише української, а й світової літератури, неодноразово ставала предметом досліджень науковців. Переважно ці праці стосувалися окремих аспектів поетичного словника та поетичного мислення М. Зерова, М. Рильського, П. Филиповича, Ю. Клена, М. Драй-Хмари. Науковці порушували питання, пов'язані зі своєрідністю художньої мови та мовотворчості неокласиків, зверталися до розгляду словесних образів, аналізували функціонування фрразеологізмів у мові поетів, відзначали специфоку звукопису та поетичного синтаксису творів.

Зв'язок проблеми з попередніми дослідженнями. Як зауважують дослідники В. Дончик [11], Ю. Кузьма [16], П. Солодько [21], І. Вакулик [3; 4; 5; 6, с. 86-108], О. Турган [23], І. Сацик [20], В. Панченко [19], В. Зварич [9], А. Калєтнік [12], О. Бриська [2], Л. Дужа [8], В. Башманівський [1], спільними для неокласиків були принципи аристократизму духу, творчого інтелекту, тяжіння до високої культури мислення й дисципліни поетичного мовлення, що й зумовлювало їхнє захоплення досконалістю античної лірики. Представники неформального товариства “неокласиків», що утворилося в Україні у 20-х роках ХХ ст., сповідували естетичну концепцію духовного оновлення свідомості письменника та нації загалом, дисциплінували кардіоцентричну стихію генерації митців (розстріляного відродження), поєднуючи діонісійську традицію з аполлонійською культурою.

Аналів останніх досліджень і публікацій. К. Леві-Строс, О. Лосєв, М. Бахтін, Ю. Апресян, А. Вежбицька, Ф. Нікітіна, І. Голубовська, досліджуючи варіанти кодування інформації у колективній пам'яті етносу, аналізували моделі так званого семіотичного трикутника, у яких згенеровано новітні смисли і за якими побудовано текстові структури. Як зауважував Г. Кнабе, трансляція культури від одного народу до іншого відбувається на трьох рівнях:

1) запозичення окремих елементів;

2) вплив унаслідок безпосереднього контакту носіїв різних культур;

3) поглинання змісту, характеру, духу й стилю минулої культурної епохи, зумовлене співзвучністю з нею та потребою в її історико-культурному досвіді [13]. Останній рівень Г. Кнабе пропонував називати “ентелехією культури», саме потреба в історико-культурному досвіді попередніх епох і стала передумовою появи української неокласики.

Постановка завдання. Мета статті - проаналізувати специфіку рецепції античних мотивів і образів у літературній спадщині українських неокласиків початку XX ст., зокрема М. Зерова і М. Рильського.

Виклад основного матеріалу. ХХ століття пройшло під девізом модернізму. Це був час новаторства, час пошуку. На літературну арену виходять різні напрямки і течії: футуристи, конструктивісти, символісти, акмеїсти, імажиністи, експресіоналісти, неокласики, (пролетарські) та (новоселянські») поети. «Проте критика вважала за сучасне лише авангардський пошук, пошук нових форм, нових засобів вираження. А це інколи зводилось до примітивізму. Унаслідок - довга низка поем, позбавлених музичності, колориту, "доброї синтакси і хорошого словника) (як писав неокласик М. Зеров). Ось чи не тому з'являється у 1922 р.:

Прекрасна пластика $і$ контур строгий

Добірний стиль, залізна колія -

Оче твоя, поезія, дорога.

(М. Зеров. Нова українська поезія. Сонети і елегії)

А М. Рильський скаже: “І всі знайшли, а я шукаю...»

У той час, коли сторінки радянських видань були переповнені гаслами на зразок “Сбросим Пушкина с корабля современности» чи “2 х $2=5$ », невелика група українських поетів об'єднались спочатку навколо журналу “Книгар», а згодом навколо видавництва “Слово», що випустило в світ збірки “Земля і вітер» П. Филиповича й “Синя далечінь» М. Рильського, пізніше - «Камену» М. Зерова, “Крізь бурю и сніг» М. Рильського і “Простір» П. Филиповича. Ці поети відмежовувалися від примітивних зразків тогочасної культури, прагнули наслідувати мистецтво минулих епох, зверталися у власній творчості до класичних взірців, зокрема до античних мотивів, тем, сюжетів і образів.

Найпослідовнішими і найталановитішими представниками цієї течії були М. Зеров і М. Рильський, люди високої культури і громадянської мужності. I хоча надто мало проіснував гурток неокласиків, вони залишили неоціненну спадщину, внесли вагомий вклад у збагачення української літератури.

М. Зеров не був першовідкривачем античності в українській культурі. До античних тем, мотивів і образів звертались Т. Шевченко, С. Руданський, П. Куліш, Л. Українка та ін. Вони використовували не лише сюжети, а й засобами мови намагались побудувати, за словами І. Франка, “волотий міст зрозуміння і спочування між нами і далекими людьми, давніми поколіннями» [22, с. 14]. Як відомо, Горацій першим переклав еолійську пісню на італійський лад. Таке ж завдання ставив і М. Зеров перенести римську поезію на український грунт, щоб прекрасною українською мовою заговорили Лукрецій і Катулл, Вергілій і Горацій, Ювенал і Овідій.

Зерова досить часто відносили, звичайно з певними застереженнями, до (каноністів». Дійсно, він був єдиним суворим неокласиком - і як теоретик, який закликав іти “до джерел» (саме таку назву 
мала збірка його літературно-критичних статей 1926 р.), і як практик-поет і перекладач, однак відомо, що М. Рильський категорично не погоджувався із зарахуванням свого колеги до архаїстів і консерваторів. Поет вбачав у його канонізмі протест проти старосвітщини і сентиментальності старих епігонських поколінь, з одного боку, з іншого - реакцію на всілякі ліві (ізми», розповсюджені у 20 -ті роки.

Спираючись на дефініції “символу» у лінгвістичній літературі $[7 ; 14 ; 15 ; 24]$, підкреслимо, що у неокласиків не було творів, що відповідали б суворим вимогам класицистичної поетики як замкнутої художньо-стильової системи з притаманними їй раціоналістичним мімезисом, статичністю, пластичністю, не дотримувалися як таких настанов, так і вимог єдності місця, часу і дії. Неокласики мали на меті оновлення культивованої ними традиційної версифікації.

Як зауважував Ю. Лотман [17], символ ніколи не належить якомусь одному синхронному зрізу культури - він завжди пронизує цей зріз по вертикалі, приходячи з минулого і йдучи в майбутнє. Пам'ять символу завжди давніша, ніж пам'ять його несимволічного текстового оточення. Як важливі механізми пам'яті культури, символи переносять тексти, сюжетні схеми та інші семіотичні утворення з одного пласта культури в інший. Константні набори символів, що пронизують діахронію культури, в значній мірі беруть на себе функцію механізмів єдності: здійснюючи пам'ять культури про себе, вони не дають їй розпастися на ізольовані хронологічні пласти.

Сім поезій із ранніх збірок М. Рильського присвячено білій водяній лілії ((Лілії водяні», “Осміяний самим собою», (Там, десь глибоко на дні), (Голос отрути» та ін.). Причому образ лілії відбиває цілий спектр значень - від уособлення чистоти, віри, стремління до ідеалу. Інша квітка - троянда - набуває рис узагальненого імені - Поет, Месниця, Кохана, Богиня.

Про поезію, написану у 1921 р., котра стала шедевром любовної лірики Рильського (йдеться про (Нашу шлюбну постелю вквітчали троянди пахучі...»), на сторінках “Червоного шляху» одразу з'явились різноманітні відгуки, серед яких зустрічаємо і рецензію В. Сосюри: «Вона простотою і силою нагадує кращі зразки античної поезії, навіть колорит автор добрав класичний, і гекзаметр тут тільки вінчає гармонію» [26]. Це були слова вдячності за (молитву подружжяя).

До символічних значень троянди (виходячи з аналізу поезій неокласиків), за якими криються концепти (краса), "досконалість), (витонченість), (радість), (любов», (задоволення), (слава», (пишність», (розкіш), (“блаженство), ((аромат», ("гордість), (мудрість), ((таємниця», ((таїна), (тиша», варто додати канон (гармонійного людського буття) (в одній із найвідоміших поезій М. Рильського (Троянда й виноград)).

Епітети М. Зерова досить витончені, цікаві своєю новизною і часто несподіваною сполучуваністю, як от: (твереза вода», (кубок веселий», (святий бич), (вінки квітчасті), (мить остання), а "роки текучі), (дзвінкий водограй» і (дикі струмки». Можливо, такої своєрідної палітри вони набувають завдяки тому, що знаходяться у постпозиції і нерідко симетрично розташовані. Таким чином підноситься рівень мовлення на свідому стилістичну настанову - інверсію. Це було необхідно Зерову, щоб перенести центр ваги від іменника на прикметник, звернути увагу на новизну і важливість його, тому “Ахілл шоломенний», “Оріон дощовитий», (ніч сновійна», (сонце світлосяйне», море - "вітрильно-крилате».

М. Рильський присвячуючи вірш М. Зерову, не наслідував його перекладацької манери, не був суворим копіїстом античних нормативів, проте став справжнім новатором, котрий на основі античної, української і російської класичної тематики створював своєрідні і водночас дуже прості, природні, прозорі форми. Поет зумів відтворити красу й повнозвучність сапфічного вірша, обмежившись мінімумом ритмічних засобів. Слід нагадати, що традицію інтерпретації античних логаедів класичними розмірами започаткував I. Франко, який переспівував сапфічні строфи (в циклі (Із Сапфони») не тільки складними логаедичними метрами, а й класичним віршем, особливо з складником «Золотії горішки щоб родились довікул [25].

Висновки. Аналізуючи естетичну платформу творчого генія неокласиків, ми звернулися до джерел формування зрізу культури доби, символіка якої сягає античності - не ізольованого пласту культури, а світоглядної системи із власним мікрокосмом. Детальний розгляд лінгвістичної інтерпретації символіки поезій М. Зерова та М. Рильського виявив послідовну рецепцію античних сюжетів, мотивів, образів, символів. Переспів античних мотивів у М. Рильського - це епікурейські мотиви та пов'язані з ними описи природи, пристрасне чи нерозділене кохання, натяки на різні міфічні істоти (Пан, кентавр, Сфінкс, Сирени), образи античних богів і героїв (Дафнна, Аполлон, Кіпріда, Флора, Діана, Деметра, Персефона, Зевс, Нарцис, Тезей, Орфей, Дедал та Ікар, Тантал). Тому ми можемо говорити про єдність основного набору домінуючих символів і тривалість їх у культурному житті, які значною мірою визначають національні і локальні кордони культур. Отже, символ став посередником між різними сферами семіозиса, а також між семіотичною і позасеміотичною реаліями, віддзеркаленням картини світу певного етносу, її художнім відбитком, у якому генетично закодований світогляд [18]. У такий спосіб М. Зеров і М. Рильський розвинули українську поетичну традицію, збагативши іiї надбаннями античної доби.

Перспективи подальших розвідок убачаємо у пошукові новітніх форм опису ментальних моделей, вербалізованих у структурі творів українських неокласиків. 


\section{Лime ратура}

1. Башманівсъкий В. I. Феномен діалогу культур у рецепції М. Зерова / В. І. Башманівський // Соціум. Документ. Комунікація . - 2016. - Вип. 2. - С. 155-163.

2. Бриська О. Я. До питання про перекладацькі методи Миколи Зерова / О. Я. Бриська // Наукові записки Національного університету „Острозька академія». Серія : Філологічна. - 2014. - Вип. 45. - С. 199-202.

3. Вакулик I. I. «Люби природу не як символ ...) / І. Вакулик // Література. Фольклор. Проблеми поетики. - К., 2012. - № 37. - C. 25-29.

4. Вакулик I. I. Інтерпретація концепту квітів у ранній творчості Рильського / І. Вакулик // Мова як світ світів. Граматика і поетика текстових структур. - Київ, 2010. - С. 37-41.

5. Вакулик I. Метрика творчої спадщини українських неокласиків / I. Вакулик, В. Кашперська // Українське мовознавство. - К., 2011. - № 40/1. - С. 245-249.

6. Вакулик I. Мова, етнос, нація у контексті гуманітарних знань : [монограффія] / І. Вакулик. - К. : ЦП «Компринт», 2016. - $184 \mathrm{c}$.

7. Домилівсъка Л. В. Лінгвістична проблематика текстової інтерпретації символу / Л. В. Домилівська // Актуальні проблеми української лінгвістики : теорія і практика. - 2008. - Вип. 17. - С. 124-132.

8. Дужа Л. I. Лексико-семантичне вираження концептів "білий», (чорний» та (червоний» у поетичній картині світу українських неокласиків (на матеріалі поезій М. Зерова, М. Драй-Хмари та П. Филипповича) / Л. I. Дужа // Лінгвістичні дослідження. - 2016. - Вип. 42. - С. 112-118.

9. Зварич В. З. Образи світової літератури у творчій рецепції поетів-неокласиків (М. Зеров, М. Драй-Хмара, М. Рильський) / В. З. Зварич // Вісник Львівського університету. Серія : Іноземні мови. - 2012. - Вип. 20(1). C. $136-144$.

10. Зеров M. Твори : у 2 т. / М. Зеров. - К. : Дніпро, 1990. - Т. 1. - 843 с.

11. Історія украӥнсъкоӥ літератури ХX столітmя: у 2 кн. - Кн. 1 : Перша половина ХХ ст. : підручник / за ред. В. Г. Дончика. - К. : Либідь, 1998. - $464 \mathrm{c.}$

12. Калєтнік A. А. Вербалізація художнього світогляду в концепції Миколи Зерова / А. А. Калєтнік // Мова і культура. - 2011. - Вип. 14. Т. 4. - С. 336-341.

13. Кнабе Г. С. Понятие энтелехии и история культуры / Г. С. Кнабе // Вопросы философии. - М., 1993. № 5. - С. $19-32$.

14. Кобиленко H. K. Кореляція понять концепт і символ у когнітивній лінгвістиці / Н. К. Кобиленко // Наукові записки Національного університету „Острозька академія». Серія : Філологічна. - 2016. - Вип. 60. - С. $35-37$.

15. Колесник О. С. Міфологічно орієнтований семіозис в аспекті квантової лінгвістики / О. С. Колесник // Науковий вісник Чернівецького університету. Германська філологія. - 2015. - Т. 740. - С. 80-85.

16. Кузьма Ю. М. Античні мотиви в поезії М. Т. Рильського // Іноземна філологія. - Львів, 1966. - Вип. 9. C. $32-39$.

17. Лотман Ю. М. Символ в системе культуры / Ю. Лотман // Избранные статьи. - Таллинн, 1992. - Т. 1. Статьи по семиотике. - С. 191-199.

18. Панасенко $K$. О. Символіка поетичного тексту як об'єкт перекладу (на матеріалі українських та російських перекладів англомовної поезії XIX-XX ст.) : дис. ... канд. філол. наук : 10.02.16 / К. О. Панасенко. - Херсон, 2015. -247 c.

19. Панченко В. Микола Зеров : формування української ідентичності / В. Панченко // Мандрівець. - К., 2013. - № 2. - C. 50-57.

20. Сацик I. $K$. Естетична концепція Миколи Зерова : калокагатія / I. К. Сацик // Гуманітарний часопис. - Харків, 2007. - № 3. - С. 61-69.

21. Солодъжо П. Ремінісценції з грецької та латини в оригінальній поезії Миколи Зерова / П. Солодько // Дивослово. - 1994. - № 12. - С. 9-11.

22. Тихолоз Б. Іван Живий, Невідомий / Б. Тихолоз // І. Франко. Украдене щастя. - Харків : Фоліо, 2011. $636 \mathrm{c.}$

23. Турган О. Рецепція античності в українській літературі (діахронічний аспект) / О. Турган // Філологічні семінари. - К. : КНУ ім. Т. Шевченка, 2013. - Вип. 16. - С. 72-81.

24. Фоменко О. С. Поняття “символ» і його осмислення у сучасній лінгвістиці / О. С. Фоменко // Проблеми семантики слова, речення та тексту. - К. : КНУ ім. Т. Шевченка, 2010. - Вип. 25. - С. $402-409$.

25. Франко I. Легенда про вічне життя / I. Франко [Електронний ресурс]. - URL : http://chtyvo.org.ua/authors/ Franko/Lehenda_pro_vichne_zhyttia/

26. Червоний шляхх. - Харків, 1923. - № 3.

References

1. Bashmanivskyi, V. I. (2016), "The phenomenon of cultural dialogue in the reception of M. Zerov", Socium. Document. Communication ["Fenomen dialohu kultur u retseptsii M. Zerova", Sotsium. Dokument. Komunikatsiia], The H. S. Skovoroda Pereyaslav-Khmelnitsky National Pedagogical University, Pereyaslav-Khmelnitsky, nr 2, pp. $155-163$.

2. Bryska, O. Ya. (2014), "Historical and theoretical conclusions as to the methodology of translation by Mykola Zerov", Scientific proceedings. Philology Series ["Do pytannia pro perekladac'ki metody Mykoly Zerova", Naukovi zapysky Nacionalnoho universytetu «Ostrozka akademiia». Serija Filolohichna], Ostroh Academy National University, Ostroh, vol. 45, pp. 199-202.

3. Vakulyk, I. I. (2012), "Love nature not as a symbol", Literature. Folklore. Problems of poetics ["Liuby pryrodu ne yak symvol", Literatura. Folklor. Problemy poetyky], The Taras Shevchenko National University of Kyiv, Kyiv, vol. 37, pp. $25-29$.

4. Vakulyk, I. I., Kashperska, V. T. (2010), "Interpretation of the concept of flowers in Rylsky early works", Language as world of worlds. Grammar and poetics of text structures ["Interpretaciia kontseptu kvitiv u rannii tvorchosti Rylskoho", Mova yak svit svitiv. Hramatyka $i$ poetyka tekstovykh struktur], The Taras Shevchenko National University, Kyiv, pp. $37-41$. 
5. Vakulyk, I. I. (2011), "The metric of the creative heritage of the Ukrainian neoclassic", Ukrainian linguistics ["Metryka tvorchoi spadshchyny ukrainskykh neoklasykiv", Ukrainske movoznavstvo], The Taras Shevchenko National University, vol. 40/1, Kyiv, pp. $245-249$

6. Vakulyk, I. I. (2016), Language, ethnic group, nation in the context of humanitarian knowledge [Mova, etnos, natsiia u konteksti humanitarnykh znan], Comprint, Kyiv, $184 \mathrm{p}$.

7. Domilovskaya, L. V. (2008), "Linguistic issues of text interpretation of the symbol", Actual problems of Ukrainian linguistics : theory and practice [Linhvistychna problematyka tekstovoi interpretatsii symvolu, Actualni problemy ukrayinskoyi lingvistyky : teorija i praktyka], The Taras Shevchenko National University of Kyiv, Kyiv, V. 17, pp. 124-132.

8. Duzha, L. I. (2016), "Lexical-semantic expression of concepts "white», (black") and "red") in the poetic world picture of Ukrainian neoclassicists (based on the poetries of M. Zerov, M. Dray-Khmara and P. Fylyppovych)", Linguistic researches ["Leksyko-semantychne vyrazhennia kontseptiv "bilyi», "chornyi» ta "chervonyi" u poetychnii kartyni svitu ukrainskykh neoklasykiv (na materiali poezii M. Zerova, M. Drai-Khmary ta P. Fylyppovycha)", Linhvistychni doslidzhennia], The H. S. Skovoroda Kharkiv National Pedagogical University, Kharkiv, vol. 42, pp. 112-118.

9. Zvarych, V. Z. (2012), "World literature images in poets-neoclassicists creative reception (M. Zerov, M. Drai-Khmara, M. Rylsky)", Visnyk of the Lviv university. Series Foreign Languages ["Obrazy svitovoi literatury u tvorchii retseptsii poetiv-neoklasykiv (M. Zerov, M. Drai-Khmara, M. Rylskyi)", Visnyk Lvivskoho universytetu. Seriia : Inozemni movy], The Ivan Franko National University of Lviv, Lviv, vol. 20(1), pp. 136-144.

10. Zerov, M. (1990), Works [Tvory], Dnipro, Kyiv, vol. 1, 843 p.

11. Donchyk, V. (1998), The history of Ukrainian literature of the $20^{\text {th }}$ century : in 2 vol. [Istoriia ukrainskoi literatury XX stolittia : $2_{2 \mathrm{kn}}$.], Swan, Kyiv, vol. $1,464 \mathrm{p}$.

12. Kaletnik, A. A. (2011), "Verbalization of artistic vision in the concept of Nikolai Zerov", Language and Culture ["Verbalizacija khudozhn'oho svitohliadu v koncepcii Mykoly Zerova", Mova $i$ kultura], The Taras Shevchenko National University of Kyiv, Kyiv, vol. 4, pp. 336-341.

13. Knabe, G. S. (1993), "The concept of entelechy and the history of culture", Studies in Philosophy ["Poniatie entelekhii i istorija kultury", Voprosy filosofii], Nauka, Moscow, vol. 5, pp. 19-32.

14. Kobylenko, N. K. '(2016), "Correlation of the notions concept and symbol in cognitive linguistics", Scientific proceedings of the National University of Ostroh Academy, Philology Series ["Koreliacija poniat' koncept i symvol u kohnityvnij linhvistyci", Naukovi zapysky Nacionalnoho universytetu «Ostroz'ka akademija». Serija : Filolohichna], Ostroh, vol. 60 , pp. $35-37$.

15. Kolesnyk, O. S. (2015), "Myth-oriented semiosis from the standpoint of quantum linguistics", Scientific bulletin of Chernivtsi University ["Myth-oriented semiosis from the standpoint of quantum linguistics", Naukovyi visnyk Chernivec'koho universytetu. Hermans'ka filolohija], Chernivtsi, vol. 740, pp. 80-85.

16. Kuzma, Iu. M. (1966), "Ancient motives in the poetry of M. T. Rylsky", Foreign philology ["Antychni motyvy v poezii M. T. Ryl's'koho", Inozemna filolohija], Lviv State University, Lvov, vol. 9, pp. 32-39.

17. Lotman, Iu. M. (1992), "Symbol in the system of culture", Selected articles, Articles on semiotics ["Simvol v sisteme kultury", Izbrannye statji. Statji po semiotike], Tallinn, vol. 1, pp. 191-199.

18. Panasenko, K. O. (2015), Symbolism of poetic text as an object of translation (based on the material of Ukrainian and Russian translations of English-language poetry of the $19^{\text {th }}-20^{\text {th }}$ centuries] : Thesis [Symvolika poetychnoho tekstu yak obiekt perekladu (na materiali ukrainskykh ta rosijskykh perekladiv anhlomovnoi poezii XIX-XX st.) : dys.... kand. filol. nauk], Kherson, 247 p.

19. Panchenko, V. (2013), "Nikolai Zerov : Formation of Ukrainian Identity", The traveler ["Mykola Zerov : formuvannia ukrajins'koi identychnosti", Mandrivets], Kyiv, vol. 2, pp. 50-57.

20. Satsyk, I. K. (2007), "The aesthetic concept of Nikolai Zerov : kalokagatiya", Humanitarian journal ["Estetychna koncepcija Mykoly Zerova : kalokahatija", Humanitarnyi chasopys], Kharkiv, vol. 3, pp. 61-69.

21. Solodko, P. (1994), "Reminiscences from Greek and Latin in the original poetry of Nikolai Zerov", Divoslovo ["Reminiscenciji z grec'koji ta latyny v oryginal'nij poeziji Mykoly Zerova", Dyvoslovo], Kyiv, vol. 12, pp. 9-12.

22. Tykholoz, B. (2011), "Ivan Live, Unknown", Stolen happiness ["Ivan Zhyvyi, Nevidomyi", I. Franko. Ukradene shchastia], Folio, Kharkiv, 636 p.

23. Turhan, O. (2013), "The Reception of Antiquity in Ukrainian Literature (Diachronic aspect)", Philological Seminars ["Recepcija antychnosti v ukrainskij literaturi (diakhronichnyj aspekt)", Filolohichni seminary], Taras Shevchenko National University, Kyiv, vol. 16 , pp. $72-81$.

24. Fomenko, O. S. (2010), "The concept of 'symbol' and its comprehension in modern linguistics", Problems of semantics of words, sentences and text ["Poniattia 'symvol' i joho osmyslennia u suchasnii linhvistyci", Problemy semantyky slova, rechennia ta tekstu], Taras Shevchenko National University, Kyiv, vol. 25, pp. 402-409.

25. Franko, I. Lehenda pro vichne zhyttia, available at : http://chtyvo.org.ua/authors/Franko/Lehenda_pro_vichne_ zhyttia/ (accessed 2 September 2017).

26. The Red Road (1923), [Chervony Shlyakh], Kharkiv, vol. 3. 


\section{ВАКУЛИК Ирина Ивановна,}

кандидат филологических наук, доцент кафедры украинского и классических языков

Национального университета биоресурсов и природопользования Украины;

ул. Героев Обороны, 15, г. Киев, 03041, Украина, тел.: +38 0506245508 ;

e-mail: vakulyk@ukr.net; ORCID ID: 0000-0002-4812-7719

БАЛАЛАЕВА Елена Юрьевна,

кандидат педагогических наук, старший преподаватель кафедры украинского и классических языков Национального университета биоресурсов и природопользования Украины;

ул. Героев Обороны, 15, г. Киев, 03041, Украина, тел.: +38 0687177254;

e-mail: olena.balalaeva@gmail.com; ORCID ID: 0000-0002-2675-5554

\section{AD FONTES: ФОРМИРОВАНИЕ ЭСТЕТИЧЕСКОЙ ПЛАТФОРМЫ В ТВОРЧЕСТВЕ Н. ЗЕРОВА И М. РЫЛЬСКОГО}

Аннотация. Цель статьи - проанализировать специфику рецепции античных мотивов и образов в литературном наследии украинских неоклассиков начала XX в., в частности Н. Зерова и М. Рыльского. Творчество неоклассиков анализируется в культурологическом и литературоведческом аспектах. Предметом рассмотрения является трансформация античных символов как механизмов (памяти культуры) и семиотических конденсаторов в синхронии текста. Результаты исследования свидетельствуют о том, что, несмотря на общее для неоклассиков тяготение к калокагатии как эстетического идеала античной культуры, которая предусматривала гармонию чувств рациональной сферы, телесного и духовного начал, высокой культуры мышления и дисциплины поэтической речи, эстетическая платформа не сводится к принципам "чистого классицизма", трактовке классических форм и принципов как универсальных и неизменных норм. Выводы. Представители эпохи "расстрелянного возрождения» оставили неоценимое наследие. Творчество неоклассиков является результатом взаимодействия традиций и новаций, национальных тенденций с заимствованным и трансформируемым опытом рецепции античного текста в мировой литературе. Н. Зеров и М. Рыльский развили украинскую поэтическую традицию, обогатили украинскую поэзию достижениями античной литературы.

Ключевые слова: украинские неоклассики, античность, рецепция, семиозис, эстетический идеал, ad fontes.

Iryna I. VAKULYK,

PhD (Philology), Associate Professor, Chair of Ukrainian and Latin languages at National University of Life and Environmental Sciences of Ukraine;

Heroyiv Oborony st., 15, Kyiv - 03041, Ukraine; tel.: +38 0506245508 ;

e-mail: vakulyk@ukr.net; ORCID ID: 0000-0002-4812-7719

Olena Yu. BALALAIEVA,

PhD (Pedagogy), Senior Lecturer, teaches Latin language at National University

of Life and Environmental Sciences of Ukraine;

Heroyiv Oborony st., 15, Kyiv - 03041, Ukraine; tel.: +38 0506245508 ;

e-mail: olena.balalaeva@gmail.com; ORCID ID: 0000-0002-2675-5554

\section{AD FONTES: FORMATION OF AESTHETIC PLATFORM IN THE CREATION OF M. ZEROV AND M. RYLSKY}

Summary. The object. The article analyzes the specifics of the perception of ancient motifs and images in the literary heritage of Ukrainian neoclassicists of the early 20th century, in particular M. Zerov and M. Rylsky. The poetry of Neo-Classicism representatives is considered in cultural and literary aspects. The subject of this study is symbols transformation as the mechanisms of (culture's memory") and semiotic capacitors in the text synchrony. Conclusion. The works of Ukrainian neoclassicists as the representatives of the era of "Executed Renaissance» have left an invaluable heritage. The poetry of neoclassicists is the result of the interaction of traditions and innovations, national tendencies with the borrowed and transformed experience of an ancient text perception in the world literature. Finding. The article proves that in spite of the common for neoclassicists attraction to kalokagathia as an aesthetic ideal of an ancient culture, which included the harmony of senses of a rational sphere, physical and spiritual roots, high culture of thinking and the discipline of poetic speech, the aesthetic platform of Zerov and Rylsky does not come down to the principles of "pure classicism", the interpretation of classical forms and principles as universal and unchanging norms.

Key words: Ukrainian neoclassicists, antiquity, perception, semiosis, aesthetic ideal, ad fontes.

Статтю отримано 10.09.2017 p. 